\title{
SOME NEW REFINED HARDY-TYPE INEQUALITIES WITH KERNELS
}

\author{
AlEKSANDRA ČIŽMEŠIJA, KRISTINA KRULIĆ AND Josip PEČARIĆ
}

\begin{abstract}
By using the notion of the subdifferential of a convex function, we state and prove a new general refined weighted Hardy-type inequality for convex functions and the integral operator with a non-negative kernel. We point out that the obtained result generalizes and refines the classical one-dimensional Hardy's, Pólya-Knopp's, and Hardy-Hilbert's inequalities, as well as related dual inequalities. We show that our results may be seen as generalizations of some recent results related to Riemann-Liouville's and Weyl's operator, as well as a generalization and a refinement of the so-called Godunova's inequality.
\end{abstract}

Mathematics subject classification (2010): 26D10, 26D15.

Keywords and phrases: Hardy's inequality, Hardy-Hilbert's inequality, weights, power weights, convex functions, Hardy's integral operator, kernel.

\section{REFERENCES}

[1] M. Abramowitz AND I. A. STEGUn (EDS.), Handbook of mathematical functions with formulas, graphs and mathematical tables, $9^{\text {th }}$ printing, Dover, New York, 1972.

[2] K. F. ANDERSEN, Weighted inequalities for the Stieltjes transformation and Hilbert's double series, Proc. Roy. Soc. Edinburgh Sect. A 86(1-2) (1980), 75-84.

[3] R. P. BoAs, Some integral inequalities related to Hardy's inequality, J. Anal. Math. 23 (1970), 53-63.

[4] A. ČIŽMeŠIJA, S. Huss AIn, AND J. PeČARIĆ, Some new refinements of Hardy and Pólya-Knopp's inequalities, J. Function Spaces Appl, 7(2) (2009), 167-186.

[5] A. ČIŽMešIJA AND J. PeČARIĆ, Mixed means and Hardy's inequality, Math. Inequal. Appl. 1(4) (1998), 491-506.

[6] A. ČIŽMEŠIJA AND J. PEČARIĆ, Classical Hardy's and Carleman's inequalities and mixed means, in: T. M. Rassias (ed.), Survey on Classical Inequalities, Kluwer Academic Publishers, Dordrecht/Boston/London, 2000, 27-65.

[7] A. ČIŽMeŠIJA AND J. PeČARIĆ, Some new generalizations of inequalities of Hardy and LevinCochran-Lee, Bull. Austral. Math. Soc. 63(1) (2001), 105-113.

[8] A. ČIŽMEŠIJA AND J. PEČARIĆ, On Bicheng-Debnath's generalizations of Hardy's integral inequality, Int. J. Math. Math. Sci. 27(4) (2001), 237-250.

[9] A. ČIŽMeŠIJA, J. PEČARIĆ, AND L.-E. PERSSON, On strengthened Hardy and Pólya-Knopp's inequalities, J. Approx. Theory 125 (2003), 74-84.

[10] W. D. Evans, A. Gogatishvili, AND B. OpIC, The $\rho$-quasiconcave functions and weighted inequalities, in: C. Bandle, A. Gilány, L. Losonczi, Z. Páles, and M. Plum (eds.), Inequalities and Applications. Conference on Inequalities and Applications, Noszvaj (Hungary), September 2007, International Series of Numerical Mathematics, Vol. 157, 121-132, Birkhäuser, Basel/Boston/Berlin, 2008.

[11] E. K. Godunova, Generalization of a two-parameter Hilbert inequality (in Russian), Izv. Vyš̌. Učebn. Zaved. Matematika 1967 54(1) (1967), 35-39.

[12] G. H. Hardy, J. E. LitTlewood, And G. Pólya, Inequalities, $2^{\text {nd }}$ edition, Cambridge University Press, Cambridge, 1967. 
[13] H. P. HeINIG, A note on Hardy's inequality in Orlitz spaces, in: Fourier analysis and partial differential equations (Miraflores de la Sierra, 1992), 185-194, Stud. Adv. Math., CRC, Boca Raton, FL, USA, 1995.

[14] M. Johansson, L.-E. Persson, And A. Wedestig, Carleman's inequality: history, proofs and some new generalizations, JIPAM J. Inequal. Appl. Math. 3(4) (2003), 19 pages, electronic.

[15] S. Kaijser, L.-E. Persson, AND A. ÖBerg, On Carleman and Knopp's Inequalities, J. Approx. Theory 117 (2002), 140-151.

[16] S. Kaijser, L. Nikolova, L-E. Persson, And A. Wedestig, Hardy type inequalities via convexity, Math. Inequal. Appl. 8(3) (2005), 403-417.

[17] R. Kerman, Construction of weights in modular inequalities involving operators of Hardy type, in: H. Hudzik, L. Skrzypczak (eds.), Function spaces. The fifth conference: Proceedings of the conference at Poznań, Poland, 1998, Lecture Notes in Pure and Appl. Math. 213, 269-278, Marcel Dekker, New York/Basel, 2000.

[18] K. Krulić, J. PeČArić, And L.-E. Persson, A new Hardy-type inequality with kernel, Math. Inequal. Appl.12(3) (2009), 473-485.

[19] A. Kufner, L. Maligranda, And L.-E. Persson, The prehistory of the Hardy inequality, Amer. Math. Monthly 113 (2006), 715-732.

[20] A. Kufner, L. Maligranda, And L.-E. Persson, The Hardy inequality - about its history and some related results, Vydavatelsky Servis Publishing House, Pilsen, 2007.

[21] A. Kufner And L.-E. Persson, Weighted Inequalities of Hardy Type, World Scientific Publishing Co, Singapore/New Jersey/London/Hong Kong, 2003.

[22] Q. LAI, Weighted modular inequalities for Hardy type operators, Proc. London Math. Soc. (3) 79(3) (1999), 649-672.

[23] N. Levinson, Generalizations of an inequality of Hardy, Duke Math. J. 31 (1964), 389-394.

[24] C. Niculescu AND L.-E. Persson, Convex functions and their applications. A contemporary approach, CMC Books in Mathematics, Springer, New York, 2006.

[25] J. A. Oguntuase, L.-E. Persson, AND A. ČIžMeŠIJA, Multidimensional Hardy-type Inequalities via convexity, Bull. Austral. Math. Soc. 77 (2008), 245-260.

[26] J. E. PeČARIĆ, F. Proschan, AND Y. L. TONG, Convex functions, partial orderings, and statistical applications, Academic Press, San Diego, 1992.

[27] G. Sinnamon, A note on the Stieltjes transformation, Proc. Roy. Soc. Edinburgh Sect A 110 (1988), 73-78.

[28] B. YANG AND T. M. RASSIAS, On the way of weight coefficents and research for the Hilbert-type inequalities, Math. Inequal. Appl. 6(4) (2003), 625-658. 